\title{
PERSEPSI MAHASISWA TERHADAP KUALITAS PELAYANAN REFERENSI DI UPT PERPUSTAKAAN UNPAD
}

\author{
Mulyani $^{1}$, Rohanda ${ }^{2}$ \\ ${ }^{1}$ UPT Perpustakaan Unpad, ${ }^{2}$ Ilmu Perpustakaan Unpad \\ ${ }^{1}$ mulyani_wungkul@yahoo.com, ${ }^{2}$ Rohanda@unpad.ac.id
}

\begin{abstract}
In this study, the authors wanted to determine and analyze the students' perceptions about the quality of service in the reference section UPT Padjadjaran, namely: Tengible element 'Physical', Realibility 'reliability', Responsive 'Response', Assurance 'Guarantee', and Empathy 'attention.' Meanwhile, the method used is exploratory, descriptive, and qualitative. The results showed that the hypothesis of the authors about the quality of service at the Library Unit Padjadjaran reference services there are still weaknesses evident. There are two drawbacks perceived by respondents as the visitors, namely: less complete collection and not humourist librarians in service to the visitors. It is expected to be input for the librarians at Padjadjaran University Library Unit that needs to be improved so that the quality of services librarians increased interest in reading them because they feel "comfortable" being in this reference section.
\end{abstract}

Keywords: Student perception, Quality Service, Library on University

ABSTRAK - Dalam penelitian ini, penulis ingin mengetahui dan menganalisis persepsi mahasiswa tentang kualitas pelayanan di bagian referensi UPT Unpad, yaitu: unsur Tengible 'Fisik', Realibility 'Kehandalan', Responsive 'Daya Tanggap', Assurance 'Jaminan', dan Emphaty 'Perhatian.' Adapun, metode yang digunakan adalah eksploratif, deskriptif, dan kualitatif. Hasil penelitian menunjukkan bahwa hipotesis penulis tentang kualitas pelayanan di bagian pelayanan referensi UPT Perpustakaan Unpad masih terdapat kelemahan terbukti. Ada dua kelemahan yang dipersepsikan oleh responden sebagai pemustaka, yaitu: kekuranglengkapan koleksi dan kekuranghumoran pustakawan dalam pelayanan terhadap pemustaka. Hal ini diharapkan dapat menjadi masukan bagi para pustakawan di UPT
Perpustakaan Unpad bahwa perlu ditingkatkan kualitas pelayanan para pustakawan sehingga minat baca mereka meningkat karena merasa "nyaman" berada di bagian referensi ini.

Kata kunci: Persepsi mahasiswa, Kualitas Layanan, Perpustakaan Perguruan Tinggi

\section{PENDAHULUAN}

Ada sebagian anggapan bahwa belajar di perpustakaan itu agak malas dengan sikap para petugas perpustakaan yang "kurang ramah." Benarkah demikian? Perlu ada penelitian akan hal ini. Hal ini, termasuk bagian dari empati pustakawan terhadap mahasiswa sebagai pemustaka. Dalam manajemen perpustakaan, ada istilah TERRA untuk pengukuran kualitas pelayanan. TERRA itu singkatan dari Tengible 'Fisik;, Emphaty 'Perhatian', Realibility 'Kehandalan', Responsive 'Daya Tanggap', dan Assurance 'Jaminan.'(Parasuraman, at.al. dalam Tjiptono dan Grrgorius Chanda, 2007: 133 - 135).

Kelima unsur ini menjadi tolok ukur dalam hal kualitas pelayanan. Dengan demikian, perilaku pustakawan perlu berusaha agar para pemustaka merasa "betah" berada di perpustakaan. Hal tersebut menyangkut kualitas pelayanan yang perlu selalu dilakukan. Terlepas dari hal itu, yang jelas harapan pemustaka yang 
berkunjung ke perpustakaan adalah bagaimana mereka terpenuhi baik untuk mencari berbagai sumber informasi dan ilmu pengetahuan, ataupun hanya berkunjung saja untuk mengisi waktu luang, memiliki satu keinginan ketika dia dilayani di perpustakaan yaitu dilayani oleh seorang

pustakawan yang ramah, sopan, dan anggun. Hal itu merupakan harapan bagi semua orang yang berkunjung ke perpustakaan.

Namun tidak sekadar itu, sebenarnya ada harapan lebih dari pemustaka terhadap pustakawan ketika melayani pemustaka yaitu pustakawan yang memiliki kemampuan berkomunikasi yang baik, tidak hanya ramah, sopan, dan anggun di samping kelengkapan koleksi dan kenyamanan tata ruang di bagian referensi ini. Untuk mencapai tahapan itu, pustakawan harus memiliki beberapa kompetensi dasar. Tidak hanya kompetensi dasar pustakawan yang diperoleh dari pendidikan formal, pengetahuan akan hal-hal yang berkaitan dengan teknis perpustakaan dan pemahaman terhadap tugas dan fungsi perpustakaan sebagai penyedia dan pengelola informasi saja, Namun, kemampuan di luar itu yaitu kemampuan berkomunikasi yang baik. Kemampuan berkomunikasi yang baik para pustakawan merupakan salah satu indikator bagaimana memenuhi kepuasan terhadap pemustaka ketika mereka berkunjung ke perpustakaan.

Berdasarkan uraian serta penjelasan yang telah dikemukakan pada latar belakang maka rumusan masalah dalam penelitian ini adalah sebagai berikut:
1. Bagaimana persepsi mahasiswa tentang Tengible 'Fisik' bagian referensi UPT Perpustakaan Unpad?

2. Bagaimana persepsi mahasiswa tentang Realibility 'Kehandalan bagian referensi UPT Perpustakaan Unpad?

3. Bagaimana persepsi mahasiswa tentang Responsive 'Daya Tanggap.' bagian referensi UPT Perpustakaan Unpad?

4. Bagaimana persepsi mahasiswa tentang Assurance 'Jaminan.'bagian referensi UPT Perpustakaan Unpad?

5. Bagaimana persepsi mahasiswa tentang Emphaty 'Perhatian bagian referensi UPT Perpustakaan Unpad?

Sesuai dengan rumusan masalah di atas, tujuan penelitian ini adalah untuk menganalisis dan mengetahui:

1. Persepsi mahasiswa tentang Tengible 'Fisik' bagian referensi UPT Perpustakaan Unpad

2. Persepsi mahasiswa tentang Realibility 'Kehandalan bagian referensi UPT Perpustakaan Unpad

3. Persepsi mahasiswa tentang Responsive 'Daya Tanggap.' bagian referensi UPT Perpustakaan Unpad

4. Persepsi mahasiswa tentang Assurance 'Jaminan.'bagian referensi UPT Perpustakaan Unpad

5. Persepsi mahasiswa tentang Emphaty 'Perhatian bagian referensi UPT Perpustakaan Unpad 


\section{TINJAUAN PUSTAKA}

Untuk memudahkan dalam memahami dan menganalisis penelitian ini, penulis menyampaikan definisi operasional mengenai topik yang penulis bahas di bawah ini:

\section{a. Persepsi Mahasiswa}

Dalam Kamus Besar Bahasa Indonesia (2007: 863) Persepsi diartikan sebagai tanggapan (penerimaan) langsung dari sesuatu. Dalam Undang-Undang Perpustakaan Nomor 43 Tahun 2007 pemustaka adalah pengguna perpustakaan, yaitu perseorangan, kelompok orang, masyarakat, atau lembaga yang memanfaatkan fasilitas layanan perpustakaan Maka jika digabungkan makna dari persepsi pemustaka adalah tanggapan atau penerimaan dari pengguna perpustakaan terhadap sesuatu hal

Dalam penelitian ini, penulis akan menggunakan kata mahasiswa sebagai wakil dari seluruh pengunjung perpustakaan baik yang menggunakan perpustakaan, ataupun tidak menggunakan perpustakaan dalam artian hanya berkunjung saja.

\section{b. Dimensi Kualitas Pelayanan}

Dimensi kualitas pelayanan ada 5, yaitu: TERRA singkatan dari Tengible 'Fisik;, Emphaty 'Perhatian' ', Realibility 'Kehandalan', Responsive 'Daya Tanggap', dan Assurance 'Jaminan.'

\section{METODE PENELITIAN}

Untuk mendapatkan hasil yang maksimal dalam penelitian ini, penulis menggunakan metode penelitian dengan pendekatan eksploratif, deskriptif, dan kualitatif. Pendekatan eksploratif dipergunakan untuk mendapatkan gambaran awal yang menyeluruh mengenai pustakawan yang memiliki kemampuan berkomunikasi yang baik menurut mahasiswa di UPT Perpustakaan Unpad. Adapun, analisis deskriptif , yaitu metode dengan cara mengumpulkan, menyajikan, dan menganalisis data. Analisis deskriptif ini bagian dari metode kuantitatif. Menurut Sugiyono (2012: 147) statistik deskriptif merupakan statistik yang digunakan untuk menganalisis data dengan cara menggambarkan data yang telah terkumpul sebagaimana adanya tanpa membuat simpuan yang berlaku secara umum. Menurut Erwina dkk (2012: 45) bahwa metode penelitian kuantitatif berdasarkan filsafat positivisme.

Metode kuantitatif digunakan untuk meneliti populasi ataupun sampel dan digunakan instrumen penelitian untuk pengumpulan data, penganalisisan data yang bersifat kuantitiatif atau statistk dengan tujuan untuk menguji hipotesis yang telah ditetapkan (Erwina. Dkk., 2012: 45). Dari kuantitatif ini lalu dijadikan kualitatif. Pendekatan kualitatif digunakan untuk mendapatkan uraian yang kaya dengan nuansa, perasaan, dan pemikiran dengan topik yang diteliti (Lutfiati, 1997: 36). Menurut Sugiono (2012: 7-8) bahwa metode kualitatif adalah metode yang menafsirkan atau menginterpretasikan data hasil penelitian di lapangan sehingga disebut juga metode interpretif. Dengan demikian, di dalam penelitian ini, penulis mencoba menafsirkan hasil pengolahan data dengan statistik/kuantitatif menjadi sesuatu yang bersifat kualitatif.

Populasi yang diteliti adalah para mahasiswa di UPT Perpustakaan Unpad. Adapun sampel 
penelitian dipilih secara purposive yaitu sampel yang dipilih sesuai dengan pendapat atau pertimbangan peneliti (Neuman, W. Laurence, 2000: 198). Metode ini memungkinkan penulis untuk memilih sampel, baik jenis maupun jumlahnya sesuai dengan pertimbangan penulis. Penelitian ini mengambil sampel 80 orang pengunjung perpustakaan atau sebesar $50 \%$ dari rata-rata kunjungan per hari pada Novembar 2014 sekitar 196 orang per hari, dan 4 orang responden sebagai sampel untuk wawancara, yang berasal dari unsur dosen, unsur karyawan, dan unsur mahasiswa.

Metode pengumpulan data menggunakan angket. Menurut Arikunto (1999: 227) metode angket merupakan metode pengumpulan data yang dilakukan dengan menggunakan sejumlah pertanyaan tertulis untuk memperoleh informasi dari responden. Adapun metode ini penulis gunakan untuk memperoleh data mengenai persepsi pemustaka terhadap kemampuan berkomunikasi pustakawan di bagian layanan sirkulasi dan bagian layanan referensi.

Adapun jenis angket yang digunakan dalam penelitian ini adalah angket dengan skala Likert. Angket skala Likert menurut Sumanto (1995: 66) merupakan instrumen yang umum digunakan untuk meminta responden agar memberikan respon terhadap beberapa statemen dengan menunjukkan apakah dia sangat setuju, setuju, tidak setuju, sangat tidak setuju terhadap setiap statemen.

Setelah penulis menyebarkan kuesioner dan melakukan wawancara dengan responden, kemudian data dikumpulkan dan dilakukan analisis. Untuk menganalisis data yang diperoleh melalui kuesioner, penulis menggunakan rumus sebagai berikut:

$\mathrm{P}=\mathrm{F} / \mathrm{N}$ X $100 \%$

$\mathrm{P}$ : persentase

F : Frekuensi yang sedang dicari persentasinya

$\mathrm{N}$ : Jumlah frekuensi/banyaknya responden

Setelah melakukan analisis dengan menggunakan rumus di atas, penulis membandingkan hasilnya antara kuesioner dengan wawancara. Kemudian penulis baru melakukan kesimpulan terhadap hasil penelitian.Adapun, teknik penyajiannya adalah jawaban responden dalam bentuk tabel yang menyatakan SS (=Sangat Setuju), S (=Setuju), CS (=Cukup Setuju), TS (= Tidak Setuju), dan STS (=Sangat Tidak Setuju) dalam bentuk persentase.

Hipotesis adalah dugaan sementara atau kesimpulan sementara terhadap penelitian, yang mungkin benar atau mungkin salah. Sehingga hipotesis akan diterima jika benar dan ditolak jika salah (Hadi, 1990: 70).

Adapun dugaan sementara penulis bahwa terdapat perbedaan persepsi pemustaka terhadap kemampuan berkomunikasi pustakawan di bagian pelayanan referensi di UPT Perpustakaan Unpad.

\section{HASIL PENELITIAN}

Setelah penulis menyebarkan angket terhadap mahasiswa di UPT Perpustakaan Unpad, langkah selanjutnya adalah mengklasifikasikan data tersebut sesuai dengan proporsinya. Dari angket yang penulis sebarkan kepada 80 mahasiswa, mendapatkan jawaban sebagaimana tersebut dalam tabel berikut ini: 
Tabel 1. Klasifikasi Data Mahasiswa UPT Unpad

\begin{tabular}{|c|c|c|c|c|c|c|}
\hline \multirow[t]{2}{*}{ No } & \multirow[t]{2}{*}{ Pernyataan } & \multicolumn{5}{|c|}{ Layanan Referensi } \\
\hline & & SS & $\mathbf{S}$ & CS & TS & STS \\
\hline 1 & $\begin{array}{l}\text { Saya merasa } \\
\text { nyaman di } \\
\text { ruangan } \\
\text { referensi. }\end{array}$ & $\begin{array}{c}27, \\
5\end{array}$ & 60 & 7,5 & 2,5 & 2,5 \\
\hline 2 & $\begin{array}{l}\text { Koleksi } \\
\text { referensi } \\
\text { sangat } \\
\text { lengkap saya } \\
\text { rasakan. }\end{array}$ & 7,5 & 25 & 52.5 & 12,5 & 2,5 \\
\hline 3 & $\begin{array}{l}\text { Pustakawan } \\
\text { memahami } \\
\text { hal yang } \\
\text { berkaitan } \\
\text { dengan } \\
\text { referensi. }\end{array}$ & $\begin{array}{c}22 \\
5\end{array}$ & $\begin{array}{c}42 \\
5\end{array}$ & 35 & 0 & 0 \\
\hline 4 & $\begin{array}{l}\text { Pustakawan } \\
\text { memahami } \\
\text { koleksi yang } \\
\text { saya } \\
\text { butuhkan. }\end{array}$ & $\begin{array}{c}22, \\
5\end{array}$ & $\begin{array}{c}47 \\
5\end{array}$ & 20 & 10 & 0 \\
\hline 5 & $\begin{array}{l}\text { Pustakawan } \\
\text { merespon } \\
\text { kesalahan } \\
\text { saya dengan } \\
\text { baik dan } \\
\text { memberikan } \\
\text { arahan apa } \\
\text { yang harus } \\
\text { saya lakukan. }\end{array}$ & 20 & $\begin{array}{c}52 \\
5\end{array}$ & 25 & 0 & 2,5 \\
\hline 6 & $\begin{array}{l}\text { Pustakawan } \\
\text { mau } \\
\text { memberikan } \\
\text { solusi dan } \\
\text { menunjukkan } \\
\text { tempat buku } \\
\text { yang dicari. } \\
\end{array}$ & $\begin{array}{c}42, \\
5\end{array}$ & $\begin{array}{c}37 \\
5\end{array}$ & 7,5 & 2,5 & 0 \\
\hline 7 & $\begin{array}{l}\text { Saya } \\
\text { menyaksikan } \\
\text { bahwa } \\
\text { pustakawan } \\
\text { sudah siap } \\
\text { melayani } \\
\text { pemustaka } \\
\text { pada pukul } \\
07.30 .\end{array}$ & $\begin{array}{c}22, \\
5\end{array}$ & 60 & 12,5 & 5 & 0 \\
\hline 8 & $\begin{array}{l}\text { Pelayanan } \\
\text { pustakawan }\end{array}$ & 40 & $\begin{array}{c}47 \\
5\end{array}$ & 12,5 & 0 & 0 \\
\hline
\end{tabular}

\begin{tabular}{|c|c|c|c|c|c|c|}
\hline $\begin{array}{l}\text { Sesuai dengan } \\
\text { aturan yang } \\
\text { berlaku. }\end{array}$ & & & & & \\
\hline $\begin{array}{l}\text { Pustakawan } \\
\text { memperhatika } \\
\text { n keluhan saya } \\
\text { dalam } \\
\text { kesulitan } \\
\text { mencari } \\
\text { referensi. }\end{array}$ & 40 & 35 & 22,5 & 2,5 & 0 \\
\hline $\begin{array}{l}\text { Pustakawan } \\
\text { menyelingi } \\
\text { pembicaraanya } \\
\text { dengan } \\
\text { bercanda } \\
\text { ringan dan } \\
\text { komunikatif. }\end{array}$ & 22, & 35 & 25 & 12,5 & 0 \\
\hline
\end{tabular}

Pertanyaan Nomor 1 dan 2 berkaitan dengan Tengible 'Fisik'. Pertanyaan Nomor 3 dan 4 berkaitan dengan Realibility 'Kehandalan.' Pertanyaan Nomor 5 dan 6 berkaitan dengan Responsive 'Daya Tanggap.' Pertanyaan Nomor 7 dan 8 berkaitan dengan Assurance 'Jaminan.' Pertanyaan Nomor 9 dan 10 berkaitan dengan Emphaty 'Perhatian.' Dari data tersebut di atas, jika dipersentasekan per item tanggapan dari mahasiswa terhadap pernyataan penulis yang merupakan indikator kualitas pelayanan pustakawan adalah sebagai berikut:

\section{Unsur Tangible 'Fisik'}

Unsur Tangilbe 'Fisik' dapat diketahui berdasarkan hasil pernyataan Nomor 1, yaitu: "Saya Merasa Nyaman di Ruangan Referensi" dan pertanyaan Nomor 2, yaitu: Koleksi Referensi Sangat Lengkap Saya Rasakan." Pada pernyataan Nomor 1, tanggapan dari pemustaka terhadap kenyaman $d i$ ruangan referensi, ada $27,5 \%$ pemustaka menanggapi 
sangat setuju, $60 \%$ pemustaka menyatakan setuju. Adapun, yang menyatakan tidak setuju dan sangat tidak setuju hanya 5\%. Jadi, yang menanggapi secara positif $87,5 \%$ dan yang cukup setuju dianggap netral atau ragu-ragu hanya $7,5 \%$. Dengan demikian, ruangan referensi dianggap sudah memadai oleh pemustaka.

Pada pernyataan Nomor 2, tanggapan pemustaka terhadap kelengkapan referensi, ada $7,5 \%$ pemustaka menanggapi dengan sangat setuju, $25 \%$ pemustaka menyatakan setuju. Adapun, yang menyatakan tidak setuju dan sangat tidak setuju 15\%. Jadi, yang menanggapi secara positif $32,5 \%$ dan yang cukup setuju dianggap netral atau ragu-ragu 52,5\%. Dengan demikian, kelengkapan koleksi referensi dianggap masih kurang.

\section{Unsur Realibility 'Kehandalan'}

Unsur Realibility 'Kehandalan' dapat diketahui berdasarkan hasil pernyataan Nomor 3, yaitu: "Pustakawan Memahami Hal yang Berkaitan dengan Referensi” dan pertanyaan Nomor 4, yaitu: "Pustakawan Memahami Koleksi yang Saya Butuhkan.” Pada pernyataan Nomor 3, tanggapan pemustaka terhadap kepahaman pustakawan tentang referensi, ada $22,5 \%$ pemustaka menanggapi dengan sangat setuju, $42,5 \%$ pemustaka menyatakan setuju. Adapun, yang menyatakan tidak setuju dan sangat tidak setuju tidak ada atau $0 \%$. Jadi, yang menanggapi secara positif $65 \%$ dan yang cukup setuju dianggap netral atau ragu-ragu hanya $35 \%$. Dengan demikian, pemahaman pustakawan terhadap referensi dianggap cukup memadai oleh pemustaka.
Pada pernyataan Nomor 4, tanggapan pemustaka terhadap kepahaman pustakawan tentang kebutuhan pemustaka, ada 22,5\% pemustaka menanggapi dengan sangat setuju dan 47,5\% pemustaka setuju. Adapun, yang menyatakan tidak setuju dan sangat tidak setuju hanya $10 \%$. Jadi, yang menanggapi secara positif $70 \%$ dan yang cukup setuju dianggap netral atau ragu-ragu hanya 20\%. Dengan demikian, pemahaman pustakawan terhadap koleksi yangdibutuhkan oleh pengunjung dianggap sudah memadai oleh pemustaka.

\section{Unsur Responsive 'Daya Tanggap'}

Unsur Responsive 'Daya Tanggap' dapat diketahui berdasarkan hasil pernyataan Nomor 5, yaitu: "Pustakawan Merespon Kesalahan Saya dengan Baik dan Memberikan Arahan apa yang harus Saya Lakukan" dan pernyataan Nomor 6, yaitu: "Pustakawan mau Memberikan Solusi dan Menunjukkan Tempat Buku yang Dicari." Pada pernyataan Nomor 5, tanggapan pemustaka terhadap respon pustakawan tentang keluhan pemustaka 20\% menanggapi dengan sangat setuju dan 52,5\% setuju. Adapun, yang menyatakan tidak setuju dan sangat tidak setuju hanya $2,5 \%$. Jadi, yang menanggapi secara positif $72,5 \%$ dan yang cukup setuju dianggap netral atau ragu-ragu hanya $2,5 \%$. Dengan demikian, respon pustakawan terhadap kekeliruan pengunjung dianggap sudah memadai oleh pemustaka.

Pada pernyataan Nomor 6, tanggapan pemustaka terhadap pustakawan mau memberikan solusi dan menunjukkan tempat buku yang dicari, ada $42,5 \%$ pemustaka menanggapi dengan sangat setuju dan 37,5\% pemustaka setuju. 
Adapun, yang menyatakan tidak setuju dan sangat tidak setuju hanya $2,5 \%$. Jadi, yang menanggapi secara positif $80 \%$ dan yang cukup setuju dianggap netral atau ragu-ragu hanya 7,5\%. Dengan demikian, kepedulian pustakawan dalam membantu pengunjung dalam pencarian rak buku dianggap sudah memadai oleh pemustaka.

\section{Unsur Assurance 'Jaminan'}

Unsur Assurance 'Jaminan' dapat diketahui berdasarkan hasil pernyataan Nomor 7, yaitu:" Saya Menyaksikan bahwa Pustakawan sudah Siap Melayani Pemustaka pada Pukul 07.30" dan pernyataan Nomor 8, yaitu: "Pelayanan Pustakawan Sesuai dengan Aturan yang Berlaku." Pada pernyataan Nomor 7, tanggapan dari pemustaka terhadap pustakawan sudah siap melayani pemustaka pada pukul 07.30 , ada 22,5\% pemustaka menanggapi sangat setuju dan $60 \%$ pemustaka menyatakan setuju. Adapun, yang menyatakan tidak setuju dan sangat tidak setuju hanya 5\%. Jadi, yang menanggapi secara positif $82,5 \%$ dan yang cukup setuju dianggap netral atau ragu-ragu hanya $12,5 \%$. Dengan demikian, ketepatan waktu kehadiran pustakawan dalam pelayanan dianggap sudah memadai oleh pemustaka.

Pada pernyataan Nomor 8, tanggapan dari pemustaka terhadap pelayanan pustakawan sesuai dengan aturan yang berlaku, ada $40 \%$ pemustaka menanggapi sangat setuju dan $47,5 \%$ pemustaka menyatakan setuju. Adapun, yang menyatakan tidak setuju dan sangat tidak setuju tidak ada atau $0 \%$. Jadi, yang menanggapi secara positif $87,5 \%$ dan yang cukup setuju dianggap netral atau raguragu hanya $12,5 \%$. Dengan demikian, kesesuaian pustakawan dengan aturan dalam pelayanan dianggap sudah sesuai oleh pemustaka.

\section{Unsur Emphaty 'Perhatian'}

Unsur Emphaty 'Perhatian' dapat diketahui berdasarkan hasil pernyataan Nomor 9,yaitu:'Pustakawan Memperhatikan Keluhan Saya dalam Kesulitan MencariReferensi” dan pernyataan Nomor 10, yaitu: "Pustakawan

\section{Menyelingi Pembicaraanya dengan Bercanda} Ringan dan Komunikatif." Pada pernyataan Nomor 9, tanggapan dari pemustaka terhadap pelayanan pustakawan sesuai dengan aturan yang berlaku, ada $40 \%$ pemustaka menanggapi sangat setuju dan $47,5 \%$ pemustaka menyatakan setuju. Adapun, yang menyatakan tidak setuju dan sangat tidak setuju tidak ada atau 0\%. Jadi, yang menanggapi secara positif $87,5 \%$ dan yang cukup setuju dianggap netral atau ragu-ragu hanya $12,5 \%$. Dengan demikian, kesesuaian pustakawan dengan aturan dalam pelayanan dianggap sudah sesuai oleh pemustaka.

Pada pernyataan Nomor 10, tanggapan dari pemustaka terhadap pustakawan menyelingi pembicaraanya dengan bercanda ringan dan komunikatif, ada $22,5 \%$ pemustaka menanggapi sangat setuju dan $35 \%$ pemustaka menyatakan setuju. Adapun, yang menyatakan tidak setuju dan sangat tidak setuju hanya $12,5 \%$. Jadi, yang menanggapi secara positif $57,5 \%$ dan yang cukup setuju dianggap netral atau ragu-ragu hanya $25 \%$. Dengan demikian, rasa humoris pustakawan terhadap pengunjung dianggap masih kurang memadai oleh pemustaka. 


\section{SIMPULAN}

Dari uraian di atas, penulis dapat memberikan kesimpulan dan saran sebagai berikut.

1. Unsur Tengible 'Fisik' yang berkaitan dengan kenyamanan di ruangan referensi dianggap sudah memadai oleh pemustaka, sedangkan kelengkapan referensi dianggap masih kurang.

2. Unsur Realibility 'Kehandalan' yang berkaitan dengan kepahaman pustakawan tentang referensi dan dianggap cukup memadai oleh pemustaka, sedangkan kepahaman pustakawan tentang koleksi yang dibutuhkan oleh pengguna dianggap sudah memadai oleh pemustaka.

3. Unsur Responsive 'Daya Tanggap' yang berkaitan dengan respon pustakawan terhadap kekeliruan pengunjung dan kepedulian pustakawan dalam membantu pengunjung dalam pencarian rak buku dianggap sudah memadai oleh pemustaka.

4. Unsur Assurance 'Jaminan.' yang berkaitan dengan ketepatan waktu kehadiran pustakawan dalam pelayanan dianggap sudah memadai oleh pemustaka, sedangkan kesesuaian pustakawan dengan aturan dalam pelayanan dianggap sudah sesuai oleh pemustaka.

5. Unsur Emphaty 'Perhatian' yang berkaitan dengan perhatian pustakawan terhadap keluhan pengungjung dianggap sudah memadai oleh pemustaka, sedangkan rasa humoris pustakawan terhadap pengunjung dianggap masih kurang memadai oleh pemustaka.
Dengan demikian hipotesis penulis tentang kualitas pelayanan di bagian pelayanan referensi UPT Perpustakaan Unpad masih terdapat kelemahan terbukti. Ada dua kelemahan yang dipersepsikan oleh responden sebagai pemustaka, yaitu: a. kekuranglengkapan koleksi dan b. kekuranghumoran pustakawan dalam pelayanan terhadap pemustaka.

Hal ini diharapkan dapat menjadi masukan bagi para pustakawan di UPT Perpustakaan Unpad bahwa perlu ditingkatkan kualitas pelayanan para pustakawan sehingga minat baca mereka meningkat karena merasa "nyaman" berada di bagian referensi ini.

\section{DAFTAR PUSTAKA}

Arikunto, Suharsimi. (1999). Prosedur Penelitian, Suatu Pendekatan Praktek. Jakarta: Rineka Cipta.

(2006). Metodelogi Penelitian. Yogyakarta: Bina Aksara.

Departemen Pendidikan Nasional. (2007). Kamus Besar Bahasa Indonesia. Jakarta: Balai Pustaka.

Erwina, Wina.dkk. (2012). Laporan Akhir" Pemetaan Budaya Baca Masyarakat Jawa Barat di 4 Wilayah 6 Kabupaten/Kota. Bandung: Pererintah Daetah Provinsi Jawa Barat, Badan Perpustakaan dan Kearsipan Daerah.

Hadi, Sutrisno. (2008). Metodologi Reasearch. Jogjakarta: Andi Offset. http://itmamblog.blogspot.com/2011/05/ persepsi-pemustaka-terhadapkemampuan.html.

Laurence, Neuman W. (2000). Social Research Methods: Qualitative and Quantitative Approaches. Boston: Allyn and Bacon.

Lutfiati, Makarim. (1997). Perilaku informasi perempuan Peneliti Bidang Ilmu-ilmu Sosial: Pola Hambatan dan Kemudahanya. Depok : Fakultas Sastra Universitas Indonesia.

Setuprini. dkk. (2012). Tracer Study: Kajian Relevansi Kemampuan Penguasaan Bahasa Asing dan Teknologi Informasi 
Lulusan Program Studi Akuntansi FE UNY Tahun 2004-2011 dengan Kebutuhan User. Yogyakarta: Program Studi Akuntansi Jurusan Pendidikan Akuntansi Fakultas Ekonomi Universitas Negeri Yogyakarta.

Sugiyono. (2012). Metode Penelitian Kuantitatif, Kuantitatif dan $R \quad \& \quad B$, Bandung, Alfabeta.

Tjiptono, Fandy dan Gregorius Chandar. (2007). Service, Quality, \&Satisfaction. Edisi 2.Yogyakarta: Andi.

Utami, Hariyadi. (2006). "Effective Communication Assertive Librarian. Pelatihan Pustakawan." Universitas Indonesia. 
